\title{
Are sardine larvae caught off northern Portugal in winter starving? An approach examining nutritional conditions
}

\author{
M. Alexandra Chícharo ${ }^{1, *}$, Eduardo Esteves ${ }^{1}$, A. Miguel P. Santos ${ }^{2}$, Antonina dos Santos ${ }^{2}$, \\ Álvaro Peliz ${ }^{2}$, Pedro Ré ${ }^{3}$ \\ ${ }^{1}$ CCMAR, FCMA, Universidade do Algarve, Campus de Gambelas, 8005-139 Faro, Portugal \\ ${ }^{2}$ Instituto de Investigação das Pescas e do Mar (IPIMAR), Avenida Brasília, 1449-006 Lisboa, Portugal \\ ${ }^{3}$ Departamento de Zoologia e Antropologia, Faculdade de Ciências da Universidade de Lisboa, 1749-016 Lisboa, Portugal
}

\begin{abstract}
Recently, winter upwelling events off western Iberia have become more frequent. This may affect the production and survival of sardine eggs and larvae through increased offshore transport. By analysis of RNA:DNA ratios, we investigated the impact of winter upwelling events on the larval condition of Sardina pilchardus larvae as a function of oceanographic conditions and food availability. Larvae were collected on a research cruise off northern Portugal in February 2000. Environmental parameters such as wind, water temperature, salinity, microzooplankton biomass and daily egg production of the calanoid copepod Calanus helgolandicus were also measured. The mean RNA:DNA ratios were relatively high, indicating that almost all larvae collected were in good condition. This was in agreement with the high microzooplankton biomass and high daily egg production of the copepod $C$. helgolandicus recorded during the same period. No adverse effects of upwelling causing offshore transport of larvae into poor feeding areas could be demonstrated because of the presence of a stratified warm plume with consequent high food production.
\end{abstract}

KEY WORDS: RNA:DNA ratios · Sardina pilchardus $\cdot$ Fish larvae - Microzooplankton biomass - Daily egg production

Resale or republication not permitted without written consent of the publisher

Annual recruitment to Sardina pilchardus stocks is highly variable; this can be reflected in overall stock abundance, thus affecting the sardine fishery (Robles et al. 1992). This species is of economic and social importance to fishing communities and the sardine industry in Portugal, Spain, France and Morocco) (Pestana 1989). Over the past few decades, there have been decreasing trends in small pelagic fish productivity off the western Iberian Peninsula (Santos et al. 2001, Borges et al. 2003). In order to be able to explain recruitment variability it is necessary to determine which environmental factors affect survival during early planktonic life-history stages. However, despite more than $100 \mathrm{yr}$ of research, the process of recruitment in fishes is still not well understood (Anderson 1988).

The Portuguese west coast lies at the northern limit of the east central Atlantic coastal upwelling system, which at this latitude is seasonal, typically occurring from April to September in response to cycles of northerly winds (Fiúza 1983). Sardina pilchardus has 1 major spawning area off the northwest Portuguese coast in the winter (Ré et al. 1990). Despite better feeding conditions for sardine larval growth in the northwest in the spring associated with a coastal upwelling, the major spawning takes place outside this season. This may be an adaptive mechanism for avoiding offshore transport in upwelling areas and associated loss of larvae from the coastal habitat (Parrish et al. 1981). Recently, winter upwelling events have become more frequent, and it has been suggested that this may affect the survival of sardine eggs and larvae through offshore transport (Santos et al. 2001, Borges et al. 2003).

Our underlying hypothesis to explain the recent decline in sardine recruitment was that the winter upwelling in the northern coast of Portugal is responsible for the advection of larvae to areas of low food availability, resulting in starvation. The aims of the study were to determine, by RNA:DNA ratios, the variations in nutritional condition measured among fieldcaught Sardina pilchardus larvae off the northern coast of Portugal in February 2000 during a winter upwelling event. In addition, we examined the effect (if any) of environmental parameters such as oceano- 
graphic conditions, zooplankton biomass and daily egg production (DEP) of Calanus helgolandicus using nucleic acid-derived indices.

Materials and methods. The field and laboratory experiments were as follows:

Field study: In February 2000, a research cruise was carried out off the northwest coast of Portugal during the sardine spawning season. The survey was carried out aboard RV 'Noruega' in 2 different sampling grids (Fig. 1: A-1 and A-2). The first sampling grid (Leg 1), with 5 transects of 16 stations each, ran perpendicular to the coast between Caminha $\left(41.6^{\circ} \mathrm{N}\right)$ and Figueira da Foz $\left(40.4^{\circ} \mathrm{N}\right)$ from 16 to 22 February (Fig. 1A-1). Within this broader sampling area, a smaller sampling grid (where high concentrations of sardine larvae had been found previously) was sampled 3 times from 23 to 29 February (Leg 2 between 23 and 24 February, Leg 3 between 25 and 27 February, Leg 4 between 28 February and $1 \mathrm{March} ; 34$ stations on each leg: Fig. 1A-2). Hydrographic observations were made at all stations using a conductivity-temperature-depth (CTD) instrument (SBE 19 SEACAT Profiler S/N 1914697-2204; with submersible pump SBE 5T).

Mesozooplankton tows (including sardine larvae) were made with a double oblique, $500 \mu \mathrm{m}$ mesh bongo net $(60 \mathrm{~cm}$ diameter). Hauls were designed to sample to about $50 \mathrm{~m}$ depth, or to about $5 \mathrm{~m}$ from the bottom in the shallow areas. After each haul, the sample was immediately sorted for sardine larvae and stored in liquid nitrogen $\left(-196^{\circ} \mathrm{C}\right)$ for later RNA:DNA ratio analysis. Microzooplankton samples (6 l each) were taken from the surface with a water sampler and filtered with a $60 \mu \mathrm{m}$ mesh net (10 cm diameter). Samples were preserved in $4 \%$ buffered formaldehyde solution for later taxonomic counts and biomass determinations.

The DEP rates of the calanoid copepod Calanus helgolandicus were determined in shipboard experiments using the techniques described by Harris et al. (2000). Adult females were collected with a $1 \mathrm{~m} \mathrm{FAO}$ net $(200 \mu \mathrm{m}$ mesh) towed vertically from $100 \mathrm{~m}$ to the surface (or from near the bottom to the surface at shallow stations). Fertilised females were immediately removed from the mixture and placed individually in bottles containing $100 \mathrm{ml}$ water from the collection area. These were incubated at in situ temperature $\left( \pm 1^{\circ} \mathrm{C}\right)$ for $24 \mathrm{~h}$. At the end of the incubation period, the contents of each bottle were preserved with $3 \%$ formalin and later transported to our laboratory for egg-counting. Because of time constraints, the DEP rates were determined for a small number of stations only: Leg 2: 7 stations; Leg 3: 5 stations; Leg 4: 1 station.

Laboratory procedures: To determine zooplankton biomass, samples were rinsed with an isotonic ammo- nium formate solution and heat-dried to a constant weight in an electric oven at $60^{\circ} \mathrm{C}$. To determine ashfree dry weight ( $\mathrm{mg} \mathrm{AFDW} \mathrm{m}^{-3}$ ), samples were burned at $450^{\circ} \mathrm{C}$ for $3 \mathrm{~h}$, in a muffle-furnace. Whenever zooplankton were extremely abundant, successive subsamples (microzooplankters) were obtained with $2 \mathrm{ml}$ Stempel-type pipettes.

We measured the nucleic acid content of 156 sardine larvae. The number of sardine larvae analysed depended on the quantity frozen immediately after capture at each station.

Before freeze-drying the sardine larvae, the standard lengths of thawed sardine larvae were determined under a dissecting microscope using an ocular micrometer. These lengths were corrected for shrinkage in the net in accordance with Theilacker (1980) and for shrinking in liquid nitrogen Chícharo et al. (1998). RNA and DNA content of individual larvae was determined using the fluorometric technique of Esteves et al. (2000) and Chícharo et al. (2001). In this study, nucleic acids were extracted from whole individuals by adding $150 \mu \mathrm{l}$ of $1 \%$ sarcosine and crushing them on ice. Subsequent photometric fluorescence measurements were made using ethidium bromide, a specific nucleic acid fluorochrome dye.

RNA:DNA ratios equal or below 1.3 were considered to indicate starvation. This value is the mean of the RNA:DNA ratio of sardine larvae in an in situ experiment off southern Portugal in 1992 (Chícharo 1997), in which larvae in net containers of $10 \mu \mathrm{m}$ mesh size were deprived of food for 2 to $6 \mathrm{~d}$.

Results. Oceanographic conditions: In the weeks preceding the cruise, the wind was mainly southerly and southeasterly and of light intensity. Significant southward winds began a few days before the survey, and apart from a slight ease on 20 February, these upwelling-favourable winds continued for about $2 \mathrm{wk}$ (Fig. 1). The winds were of moderate strength (about 5 to $8 \mathrm{~m} \mathrm{~s}^{-1}$ ), and constant in direction. Thus, sampling took place during the first upwelling event of the 1999 to 2000 winter, and the measurements were perfectly timed since they began a few days after the setting-in of the southward winds.

In the study area, the response of the surface layer to the upwelling-favourable winds is unusual because it occurs in a region where 2 distinct circulation features occur in winter. First, there are surface-intensified poleward flows along the slope associated with the Iberian Poleward Current (IPC) (e.g. Peliz et al. in press). Second, over the shelf, accumulated river runoff generates a persistent buoyant plume, the Western Iberia Buoyant Plume (WIBP: Peliz et al. 2002). The joint effect of the along-slope advection associated with the IPC (and its mesoscale structures) and the buoyant input of the WIBP, together with the wind- 


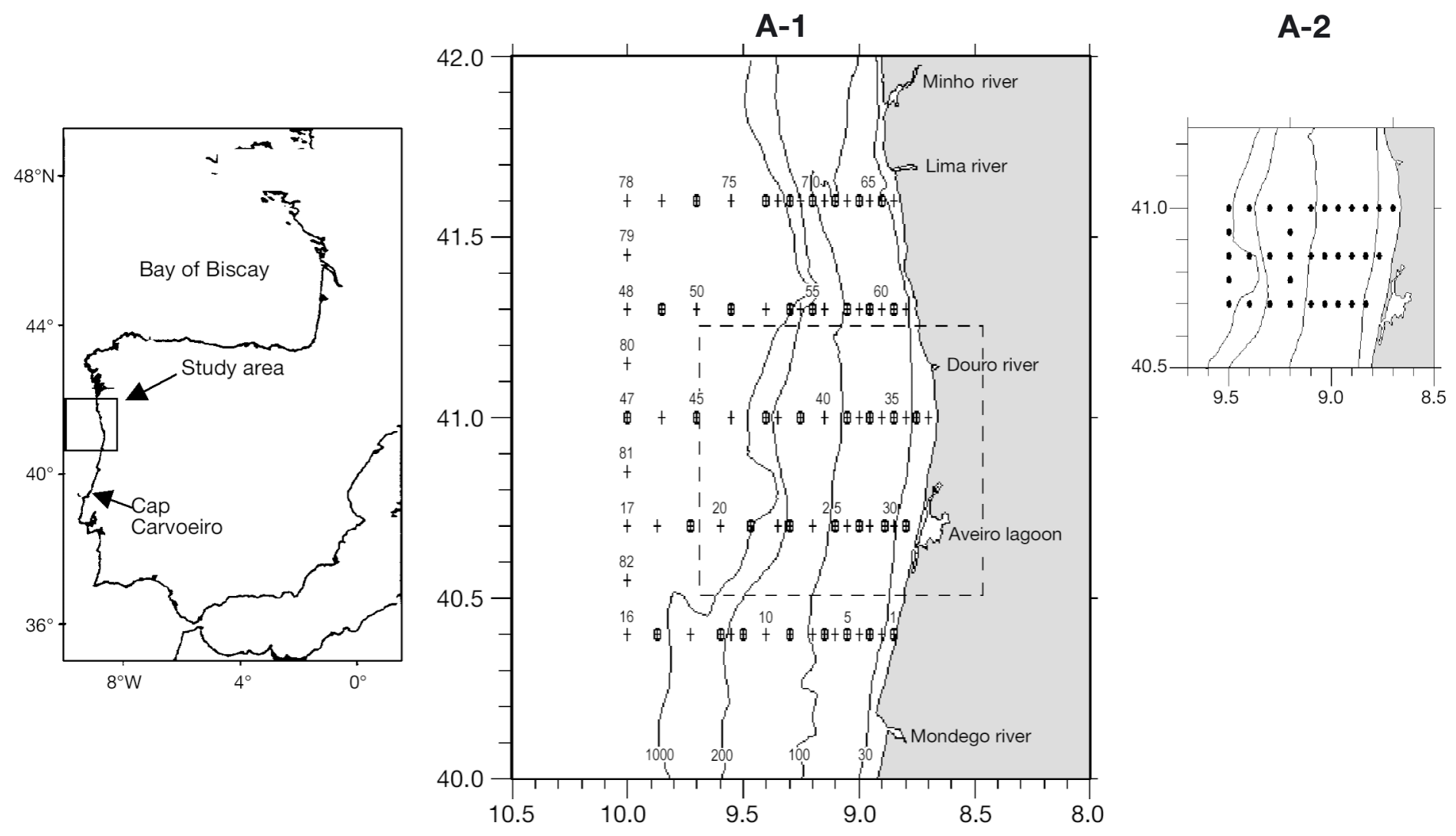

driven currents, creates a complex circulation scenario. (Details of the hydrodynamics and larval dispersal patterns are given in Santos et al. 2003, and of the phytoplankton biomass response to the wind event in Ribeiro et al. in press.) Here, we summarise the main features of the hydrology.

Fig. 2 shows 2 satellite images of the sea surface temperature (SST) for 12 and 19 February 2000, i.e. at the beginning and approximately $1 \mathrm{wk}$ after the setting-in of the southward winds (see Fig. 1B). Fig. 2 illustrates the 2 features described, i.e. the IPC and the WIBP. The WIBP, notable for a cold anomaly in the SST field, was confined to the shelf on 12 February, and had extended seawards (almost $100 \mathrm{~km}$ off the shelf break) by 19 February. The IPC is identifiable by a warm-water band on 12 February (see the thermal patterns along the isobaths in Fig. 2A). This latter feature is not visible in the SST image on 19 February. In fact, the IPC had not disappeared but was capped by the cold (significantly fresher) waters of the WIBP (Fig. 2A). This is clearly illustrated in Fig. 3B, which shows salinity in the north of the survey area $\left(41.6^{\circ} \mathrm{N}\right)$ on about 20 February. The lowsalinity waters of the WIBP (values $<35.7 \mathrm{psu}$ ) have been advected off the slope and stretch seawards, and the plume has crossed over the warm and salty along-slope IPC (identified by an isolated subsurface

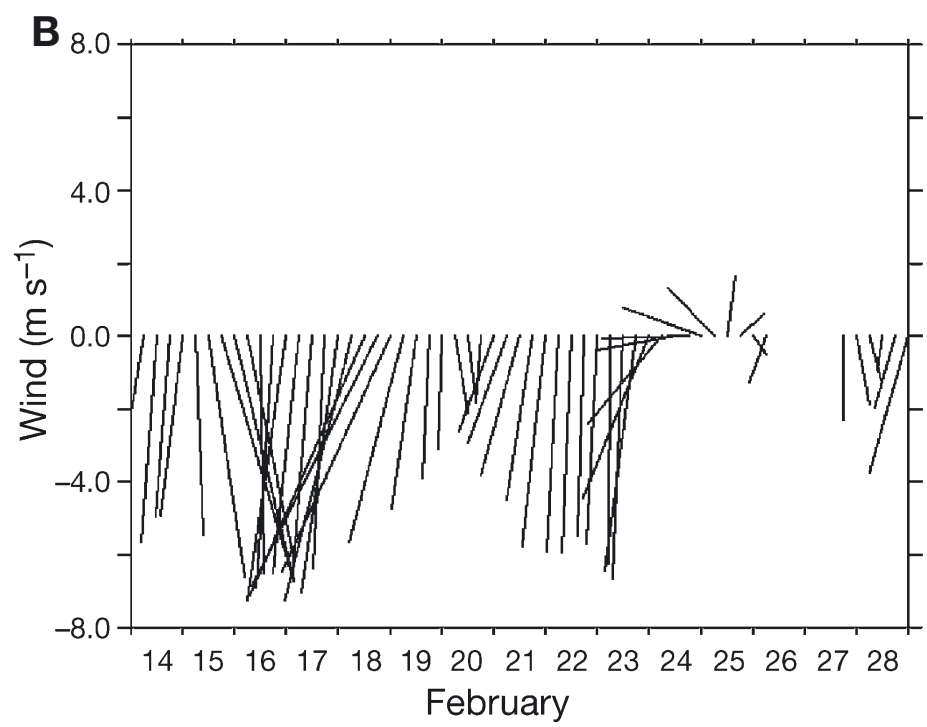

Fig. 1. (A-1, A-2) Locations of sampling grids off northern Portugal in February to March 2000. (A-1) Leg 1: large sampling grid (16 to 22 February) including all stations; (A-2) small grid with 3 replicate sampling periods (Leg 2 between 23 and 24 February, Leg 3 between 25 and 27 February, and Leg 4 between 28 February and 1 March). (B) Stick diagram of wind speed measured every $6 \mathrm{~h}$ at Cabo Carvoeiro $\left(39.36^{\circ} \mathrm{N}, 9.40^{\circ} \mathrm{W}\right)$ by Portuguese Meteorological Office between 10 and 28 February 2000. Negative values correspond to northerly winds 

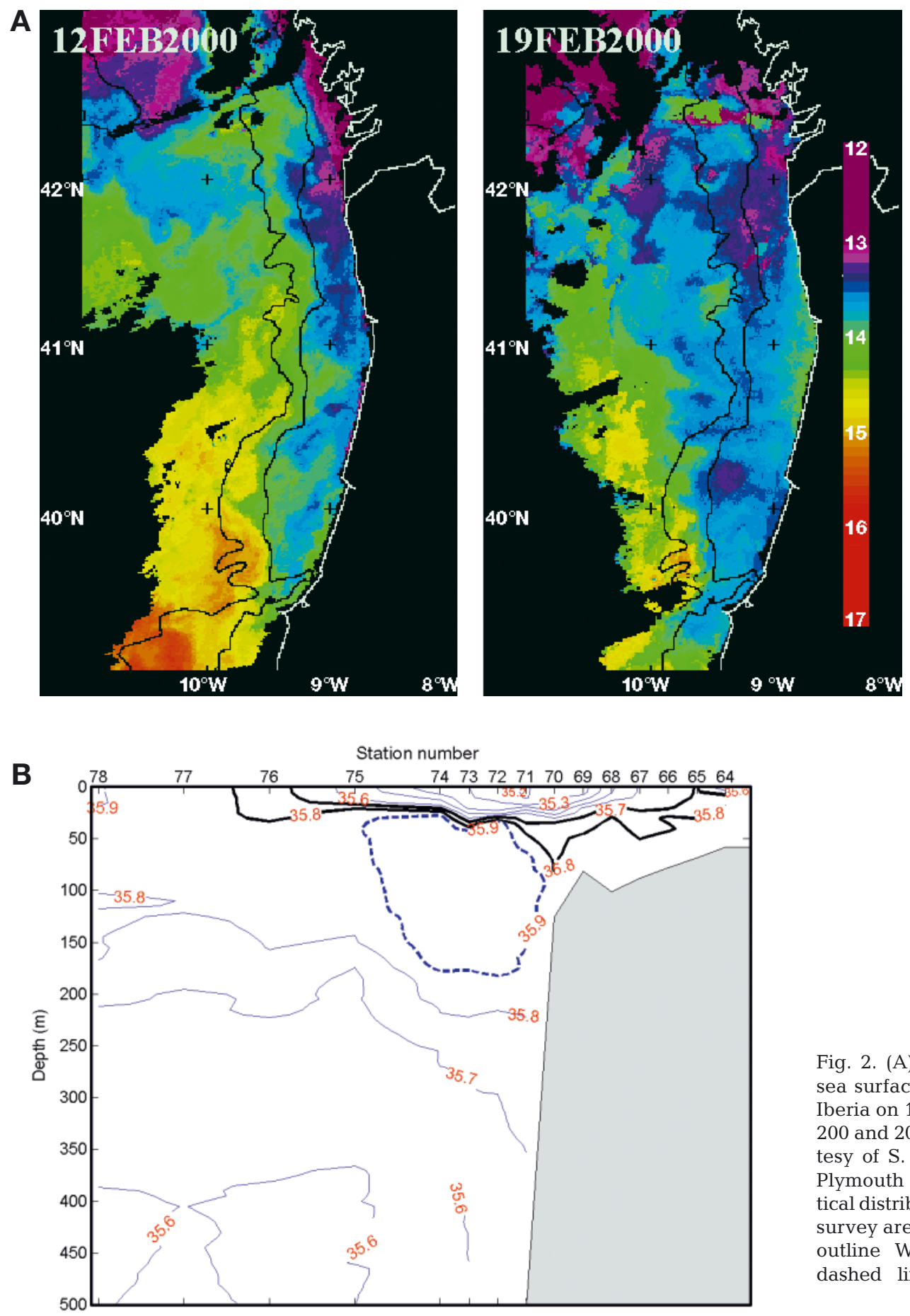

Fig. 2. (A) Distribution of satellite-derived sea surface temperature $\left({ }^{\circ} \mathrm{C}\right)$ off northwest Iberia on 12 and 19 February 2000 showing 200 and $2000 \mathrm{~m}$ isobaths (black lines) (courtesy of S. Groom, Remote Sensing Group, Plymouth Marine Laboratory, UK). (B) Vertical distribution of salinity in the north of the survey area (Stns 65 to 78); thick black lines outline Western Iberian Buoyant Plume; dashed line rings the Iberan Poleward Current

salinity core with values $>35.9$ psu; Fig. 2B). Off the slope (Stns 77 and 78), the ocean surface is characterised by a deep (100 to $150 \mathrm{~m}$ ) mixed layer.

Potential zooplankton prey abundance, biomass, and daily egg production: The microplankton consisted almost entirely of nauplii and invertebrate eggs, which frequently represented between 37 and $96 \%$ of total zooplankton abundance. The mean zooplank- ton biomass (AFDW) was highest on Leg 2 (mean = $0.287 \mathrm{mg} \mathrm{m}^{-3}, \mathrm{SD}=0.23 \mathrm{mg} \mathrm{m}^{-3}$; Table 1). High zooplankton biomass was recorded near the shore and above the slope (Fig. 3A). The DEP rates of Calanus helgolandicus measured in shipboard incubations ranged from 2.0 to 31.5 eggs female ${ }^{-1} \mathrm{~d}^{-1}$ for the period 23 to 28 February 2000. The highest value was on Leg 4 at the end of the cruise (31.5 eggs female $\mathrm{e}^{-1} \mathrm{~d}^{-1}$; Table 1$)$. 
Table 1. Mean $( \pm \mathrm{SD})$ zooplankton biomass (ash-free dry wt [AFDW]), daily egg production rates (DEP), Sardina pilchardus sardine larvae standard length (SL), $\mu \mathrm{g}$ DNA larva ${ }^{-1} ; \mu \mathrm{g} \mathrm{RNA} \mathrm{larva}^{-1}$ and RNA:DNA ratios on Legs 1 to 4 of cruise. For AFDW and $\mathrm{DEP}, \mathrm{N}=$ number of stations; for length and biochemical components, $\mathrm{N}=$ number of larvae

\begin{tabular}{|c|c|c|c|c|c|c|c|c|c|}
\hline Leg & $\mathrm{N}$ & $\begin{array}{l}\text { AFDW } \\
\left(\mathrm{mg} \mathrm{m}^{-3}\right)\end{array}$ & $\begin{array}{c}\text { DEP } \\
\left(\text { eggs female }{ }^{-1} \mathrm{~d}^{-1}\right)\end{array}$ & $\mathrm{N}$ & $\begin{array}{c}\mathrm{SL} \\
(\mathrm{mm})\end{array}$ & $\mathrm{N}$ & $\mu \mathrm{g}$ DNA larva ${ }^{-1}$ & $\mu \mathrm{g}$ RNA larva ${ }^{-1}$ & RNA:DNA \\
\hline 1 & & & & & $14.68 \pm 3.80$ & 21 & $24.95 \pm 29.66$ & $223.7 \pm 316.98$ & $6.16 \pm 3.03$ \\
\hline 2 & 16 & $0.29 \pm 0.23$ & $4.5 \pm 2.50$ & 7 & $15.57 \pm 4.15$ & 46 & $57.38 \pm 118.88$ & $288.54 \pm 579.23$ & $5.29 \pm 2.05$ \\
\hline 3 & 23 & $0.2 \pm 0.12$ & $6.91 \pm 6.67$ & 5 & $16.6 \pm 3.68$ & 50 & $47.77 \pm 103.06$ & $237.49 \pm 402.20$ & $5.72 \pm 1.88$ \\
\hline 4 & 23 & $0.2 \pm 0.12$ & 31.50 & 1 & $16.48 \pm 2.62$ & 39 & $23.93 \pm 18.08$ & $126.02 \pm 90.85$ & $5.54 \pm 2.11$ \\
\hline Mean & 62 & $0.21 \pm 0.17$ & $14.30 \pm 14.90$ & & $16 \pm 3.65$ & 156 & $41.57 \pm 88.64$ & $222.82 \pm 408.95$ & $5.61 \pm 2.17$ \\
\hline
\end{tabular}

Nutritional condition and starvation: The average RNA:DNA ratios were relatively high (mean 5.61, S.D $2.17, \mathrm{n}=156$ ) (Table 1). The majority of larvae caught during the cruise had RNA:DNA ratios between 4.0 and 6.0 (Fig. 3B). There were no significant correlations between RNA:DNA ratios and length $(r=0.127$, $\mathrm{p}<0.12$ ). There were significant correlations between RNA:DNA ratios and zooplankton biomass (AFDW) $(\mathrm{r}=0.603, \mathrm{p}<0.015)$, with high values of this ratio recorded off the coast (Fig. 3B). Starvation was very low: only $1(0.64 \%)$ out of the 156 larvae collected starved during the whole cruise.
Discussion. Our results confirm the existence of a winter upwelling event off the northern coast of Portugal during the cruise and, consequently, conditions suitable for the offshore transport of sardine larvae. Nevertheless, during the last leg of the cruise there was a change in the wind direction and a situation of convergence. Upwelling events may not have an immediate impact on the survival of sardine early-life stages due to offshore transport alone; however, on a longer time scale, there could be a negative impact arising from a combination of offshore advection and the presence of a shelf break/slope poleward current
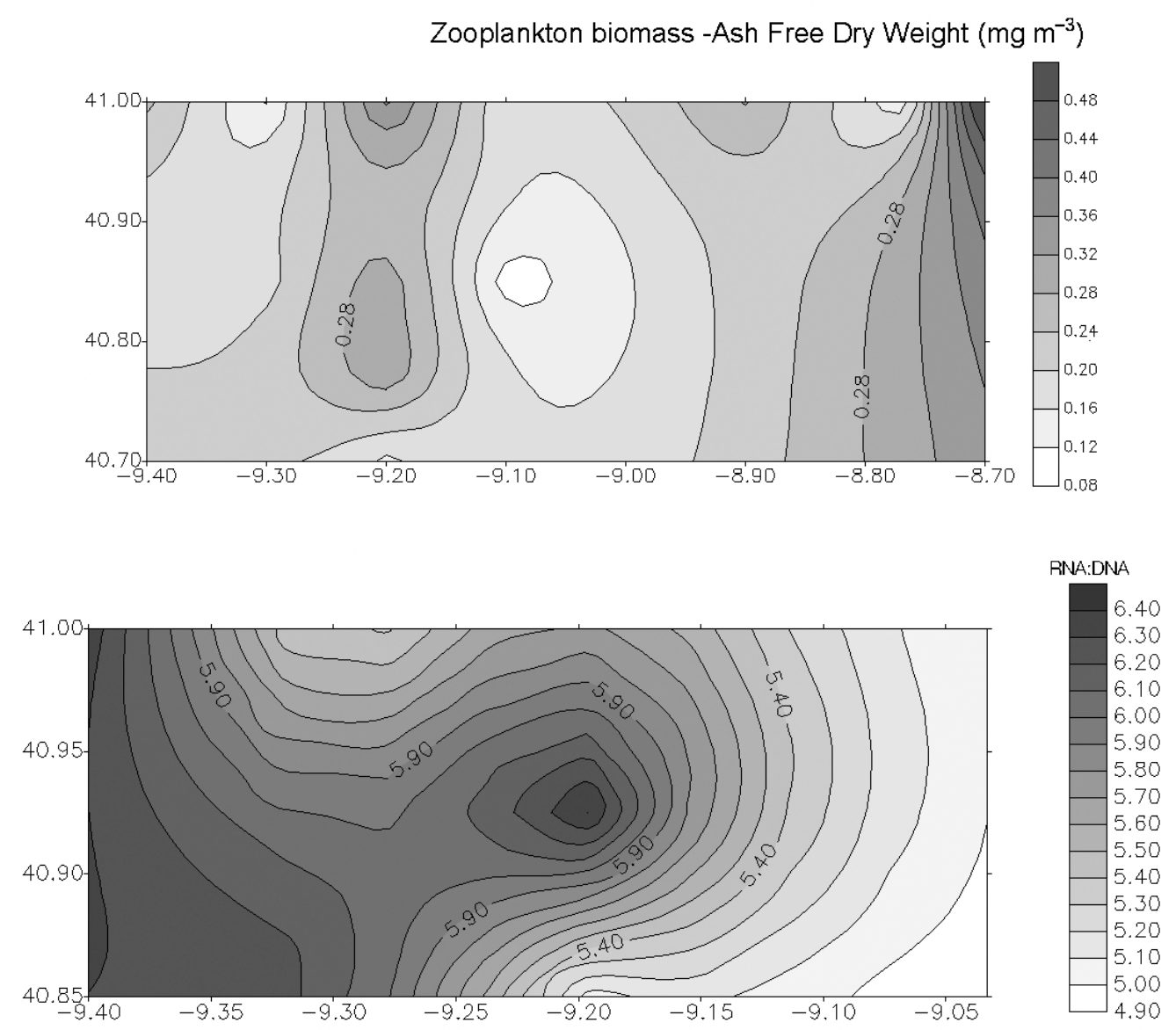

Fig. 3. (A) Microzooplankton biomass; (B) RNA:DNA ratios of Sardinus pilchardus larvae. Variation on all replicate cruise legs 
(Peliz et al. in press) that favours advection of sardine eggs and larvae from the spawning area. The abundance of sardine larvae increased towards the continental slope (Santos et al. 2003). According to our hypothesis, the upwelling event would be responsible for their advection to unfavourable feeding areas; nevertheless, we caught larvae in relatively good condition, with a high RNA:DNA ratio, away from the coast. In fact, only 1 of the 156 sardine larvae $(0.64 \%)$ collected during the cruise was classified as starving. This result is lower than the $4.8 \%$ found for sardine larvae collected on the Algarve continental shelf (southern Portugal) in the most productive season, spring (May 1992; Chícharo 1997, 1998) and lower than the $0.84 \%$ for sardine larvae collected off the north of Spain during March to June 1992 (Chícharo et al. 1998). Moreover, the general condition of the sardine larvae (evidenced by their RNA:DNA ratios) in the present study was very good. These results can be explained by the high food availability at the time of the study, as reflected in the high zooplankton biomass and DEP of copepods. Zooplankton biomass was higher than during the studies of Chícharo (1997, 1998) and Chícharo et al. (1998). This could explain part of the variation in the RNA:DNA ratios revealed by the significant correlation between the RNA:DNA ratios index and the abundance of the potential prey of sardine larvae. However, as zooplankton concentration or biomass estimates may underestimate prey availability when zooplankton is being consumed as quickly as it is produced (Hunter 1981), we determined DEP rates also. Our results for Calanus helgolandicus, observed for the first time off the Portuguese coast, are similar to those for C. helgolandicus in coastal waters off Plymouth, UK (Pond et al. 1996, Irigoien et al. 2000) at the same time of year; even the highest peak (31.5 eggs female ${ }^{-1} \mathrm{~d}^{-1}$ ) corresponds to the maximum production for this species in the Plymouth area. In Portuguese coastal waters, the DEP rate of the copepod Euchaeta hebes (Cruz dos Santos 1992) was not considered, although this species is of equal importance as food for the sardines. Therefore, our DEP values could be underestimates.

We cannot support our hypothesis that winter upwelling conditions are responsible for the starvation of sardine larvae through their advection to areas of low food availability: due to stratification, the upwelling plume is advected offshore within a shallow Ekman layer and interacts with the slope-current; this induces meridional elongation and retention close to the upper slope (see the location of the salinity minima at Stns 72 and 73; Fig. 2B). In this process, low mixing with offshore mixed-water layers guarantees the conservation of static stability to a level necessary for phytoplankton growth and for the vertical retention of ichthyo- plankton. This is in agreement with Govoni \& Chester (1990), Grimes \& Finucane (1991) and Sabatés et al. (2001), who stated that plumes of continental freshwater support the growth and survival of fish larvae.

Acknowledgements. This research was funded by the project 'Assessing the Impact of Hydrodynamic Forcing on the Survival of Small Pelagic Fish Early Life Stages of Western Iberia (SURVIVAL)' (FCT-PRAXIS/P/CTE/11282/1998). SURVIVAL is a project affiliated with GLOBEC. Thanks are due to Marcelo de Vasconcelos, the crew of the RV 'Noruega', the PELAGICOS programme (FCT-IPIMAR), and to all persons who provided data or participated in the cruises. We would like to thank Xavier Irigoien for providing assistance with the egg and copepod production techniques.

\section{LITERATURE CITED}

Anderson JT (1988) A review of size dependent survival during pre-recruit stages of fishes in relation to recruitment. J Northwest Atl Fish Sci 8:55-56

Borges MF, Santos AMP, Crato N, Mendes H, Mota B (2003) Sardine regime shifts off Portugal: a time series analysis of catches and wind conditions. Sci Mar 67(Suppl 1):235-244

Chícharo MA (1997) Starvation percentages in field caught Sardina pilchardus larvae off southern Portugal. Sci Mar 61:507-516

Chícharo MA (1998) Nutritional condition and starvation in field caught Sardina pilchardus larvae from southern Portugal compared with some environmental factors. J Exp Mar Biol Ecol 225:123-137

Chícharo MA, Chícharo L, López-Jamar E, Valdes L, Ré P (1998) Estimation of starvation and diel variation of the RNA/DNA ratios of field caught Sardina pilchardus larvae off north of Spain. Mar Ecol Prog Ser 164:273-283

Chícharo L, Chícharo MA, Alves F, Amaral A, Pereira A, Regala J (2001) Diel variation of the RNA/DNA ratios in Crassostrea angulata (Lamarck) and Ruditapes decussatus (Linnaeus 1758) (Mollusca, Bivalvia). J Exp Mar Biol Ecol 259:121-129

Cruz dos Santos MG (1992) Ciclo anual da produção zooplanctónica na região NW da costa portuguesa (Figueira da Foz). Rel estágio. Instituto Nacional de Investigação das Pescas, Lisboa

Esteves E, Chícharo M, Pina T, Coelho ML, Andrade JP (2000) Comparison of RNA/DNA ratios obtained with two methods for nucleic acid quantification in gobiid larvae. J Exp Mar Biol Ecol 243:81-94

Fiúza AF (1983) Upwelling patterns off Portugal. In: Suess E, Thiede J (eds) Coastal upwelling: its sediment record. Part A: Responses of the sedimentary regime to present coastal upwelling. Plenum Press, New York, p 175-197

Govoni JJ, Chester AJ (1990) Diet composition of larval Leiostomus xanthurus in the Mississippi river plume. J Plankton Res 12:819-830

Grimes CB, Finucane JH (1991) Spatial distribution and abundance of larval and juvenile fish, chlorophyll and macrozooplankton around the Mississippi river discharge plume and the role of the plume in fish recruitment. Mar Ecol Prog Ser 75:109-119

Harris R, Wiebe P, Lenz J, Skjoldal HR, Huntley M (eds) (2000) ICES zooplankton methodology manual. Academic Press, New York

Hunter JR (1981) Feeding ecology and predation of marine fish larvae. In: Lasker R (ed) Marine fish larvae: morpho- 
logy, ecology and relation to fisheries, 2nd edn. Washington Sea Grant, Washington, p 34-40

Irigoien $\mathrm{X}$, Head RN, Harris RP, Cummings D, Harbour D, Meyer-Harms B (2000) Feeding selectivity and egg production of Calanus helgolandicus in the English Channel. Limnol Oceanogr 45:44-54

Parrish RH, Nelson CS, Bakun A (1981) Transport mechanisms and reproductive success of fishes in the California current. Biol Oceanogr 1:175-204

Peliz A, Rosa T, Santos AMP, Pissarra J (2002) Fronts, jets and counter flows in the western Iberia upwelling system. J Mar Syst 35:61-77

Peliz A, Dubert J, Santos AMP, Le Cann B (in press) Winter upper ocean circulation in the western Iberia basin. Fronts, eddies and poleward flows: an overview. Deep-Sea Res

Pestana MG (1989) Manancial ibérico-atlântico de sardinha (Sardina pilchardus, Walb.) Sua avaliação e medidas de gestão. Dissertação, Instituto Nacional de Investigação Científica, Lisboa

Pond D, Harris R, Head R, Harbour D (1996) Environmental and nutritional factors determining seasonal variability in the fecundity and egg viability of Calanus helgolandicus in coastal waters off Plymouth, UK. Mar Ecol Prog Ser 143: $45-63$

Editorial responsibility: Otto Kinne (Editor),

Oldendorf/Luhe, Germany
Ré P, Silva C, Cunha E, Farinha A, Menezes I, Moita T (1990) Sardine spawning off Portugal. Bol Inst Nac Investig Pesc 15:31-44

Ribeiro A, Peliz A, Santos AMP (in press) A study of the response of the chl-a biomass to a winter upwelling event off western Iberia using Sea WiFS and in situ data. DeepSea Res

Robles R, Porteiro C, Cabanas JM (1992) The stock of AtlantoIberian sardine: possible causes of variability. ICES Mar Sci Symp 195:418-423

Sabatés A, Salat J, Olivar MP (2001) Advection of continental water as an export mechanism for anchovy, Engraulis encrasicolus, larvae. Sci Mar 65(Suppl 1):77-87

Santos AMP, Borges MF, Groom S (2001) Sardine and horse mackerel recruitment and upwelling of Portugal. ICES J Mar Sci 58:589-596

Santos AMP, Peliz A, Dubert J, Oliveira PB, Angélico MM, Ré P (2003) Impact of a winter upwelling event on the distribution and transport of sardine eggs and larvae off Western Iberia: a retention mechanism. Cont Shelf Res (in press)

Theilacker GH (1980) Changes in body measurements of larval northern anchovy, Engraulis mordax, and other fishes due to handling and preservation. Fish Bull US Fish Wildl Serv 78:685-692

Submitted: December 13, 2002; Accepted: April 3, 2003 Proofs received from author(s): July 28, 2003 